\title{
Optimization of Zakat State Civil Apparatus in Poverty Reduction
}

\author{
Cynthia Hadita ${ }^{1}$, Nursariani Simatupang, S.H., M.Hum ${ }^{2}$ \\ ${ }^{1} \mathrm{PhD}$ Student, University Muhammadiyah of North Sumatera, Indonesia \\ ${ }^{2}$ Lecturer, University Muhammadiyah of North Sumatera, Indonesia
}

\begin{abstract}
Zakat for the State Civil Apparatus (ASN) is very potential to overcome poverty, But, please know about the effectiveness of zakat ASN and zakat Muslims in the city of Medan has been able to avoid the social gap between the rich and the poor and to achieve a peaceful and peaceful life prosper evenly in Medan City. The method used in making this scientific paper leads to empirical juridical legal research. The results showed that zakat is very potential to alleviate poverty.
\end{abstract}

Keywords: Poverty, Zakat, Optimization

\section{Introduction}

According to data from the Central Bureau of Statistics of Medan, the number of poor people in 2017 is 205 thousand inhabitants. The discourse that the Central Government will declare a policy that the State Civil Apparatus (ASN) is a Muslim salary will be deducted for zakat need to know whether there is a balance to stem the poverty rate that exists. The potential of zakat is very potential if used as a tool for sustainable development in solving the problem of poverty.

Instruction of the President of the Republic of Indonesia Number 3 Year 2014 on the Optimization of Zakat Collection in Ministries / Agencies, Secretariat General of State Institutions, Secretariat General of State Commission, Local Government, State Owned Enterprises, and Regional Owned Enterprises through National Amil Zakat Agency (Inpres No. 3 Year 2014 on OPZ). In essence, ordered the state institutions to socialize zakat for all employees / employees who are Muslims, providing facilities for the payment of Zakat through the National Zakat Agency (BAZNAS) according to the level of good Provincial / District / City.

The need, in the digital era and globalization, utilizes technology to facilitate the process of economic equity through zakat ASN even for all Muslims to facilitate the data between zakat giver and the recipient of zakat so there is no need to spend much to provide facilities as a place of zakat payment. Zakat funds can increase the amount of social assistance funds provided by the government. Regulation as the legal basis for the implementation of zakat needs to be accommodated, especially regarding zakat ASN whose salary will be cut by 2.5 percent. Moreover, make the rules about the implementation of zakat should be implemented for all Muslims as conducted by the State of Malaysia and Saudi Arabia so that it can be optimal.

Based on the above, the authors are interested in making a scientific paper entitled: The Effectiveness of Zakat State Civil Apparatus in Poverty Alleviation in Medan City (A Case Study in the Office of National Amil Zakat Agency Medan).

\section{Research Methodology}

The method used in making this scientific paper leads to empirical juridical legal research. Sources of data used in this study are primary data and secondary data. Primary data obtained directly from the observation and interview, while secondary data obtained from scientific journals, legal literature, and legislation. Data collection techniques used in this study are observation, interview, and literature study. Data analysis technique used in this research is qualitative analysis. 


\section{Discussion}

\subsection{Theoretical framework}

Socrates explains that according to human nature then law is the order of virtue. The order that embraces virtue and justice. Virtue is none other than knowledge. According to this principle, goodness is by doing good (Bernard L. Tanya, 2013: 30-31).

Zakat is fundamentally an activity that is closely related to virtue, thus being sufficiently capable of saving an inadequate life resulting in justice evidenced by equitable welfare and no social inequality.

For Grotius, everyone has a tendency to live together. Not only that, because it has a ratio, humans also want to live in peace. Thus, Grotius made human sociability as the foundation of ontology and the foundation of all laws (Bernard L. Tanya, 2013: 63).

Peace of life can be achieved if humans as social beings are able to jointly create prosperity by helping each other through the discourse of zakat funds ASN which became the foundation for the Government to accommodate its implementation through a more detailed rules as the basis for running it due to zakat ASN the opportunity to alleviate the existing poverty by increasing the grant has been accommodated by the Government in terms of social, education, economy, natural disasters and other needs by optimizing zakat as a tool for the welfare of the people.

Law is basically a divine order. Legislation only has a function to clarify and explain the divine order (Bernard L. Tanya, 2013: 55). The existing law has not been able to explain the order of Allah SWT about the zakat so that the public is aware of his personal obligations, because in the implementation of zakat has not been implemented evenly for those who are obliged to pay to the rightful to receive it.

Based on the above theories actually optimize the application of zakat ASN in poverty alleviation very efficiently implemented, especially if Inpres no. 3 of 2014 on the existing OPZ is undertaken by appealing periodically to every institution to facilitate the payment of zakat, and by strengthening the existence of Presidential Instruction No. 3 of 2014 on the OPZ with a presidential regulation so that zakat can be managed by the government with its implementation is implemented holistically for all Muslims so that will be optimal in alleviating poverty.

\subsection{Literature Review}

Economic planning in general can be interpreted as deliberate efforts by the government to coordinate the whole process of economic development in the long run (Michael P. Todaro, 1997: 197). Formal statements can be placed within the framework of a national campaign to gain popular support for governments in alleviating poverty, eliminating ignorance and eliminating classes, caste, racial, religious or ethnic groups increasingly the reason for central government in each country to use economic planning (Michael P Todaro, 1997: 202).

The concept of zakat optimization in a country as already implemented by Malaysia and Saudi Arabia seems to have brought success. Malaysia considers zakat in every Constitution in its states and the result is capable of prospering the economy of the people. More neatly the concept of zakat in Saudi Arabia is much more integrated by utilizing information and technology that is to record nationally between the giver of zakat and the recipient of zakat so as to be able to alleviate the existing poverty. Indonesia needs to optimize the zakat ASN as an effort to alleviate poverty even more if all Muslims are appealed by the government through a rule of law on the implementation of zakat so that sustainable economic development can be implemented with the implementation of zakat through regulations and policies that support the implementation of zakat optimization.

The efficiency comparison of optimizing the empowerment of zalcat by not optimizing zakat is described in Figure 1 below: 
Optimalization of zalat

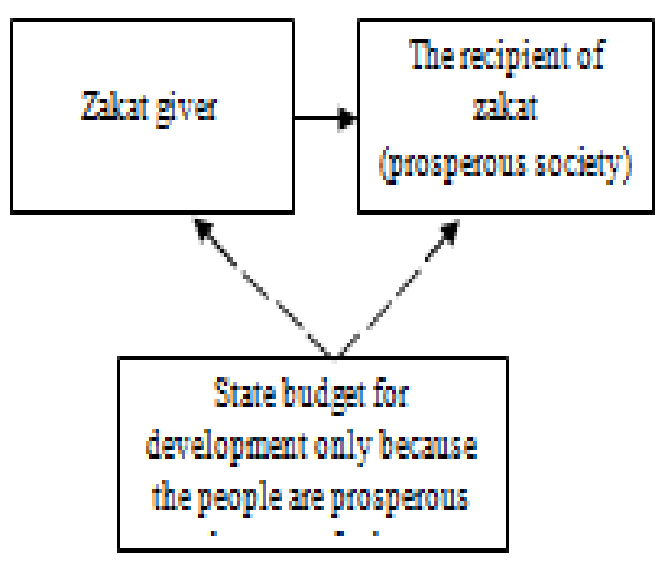

Not optimalionation zalat

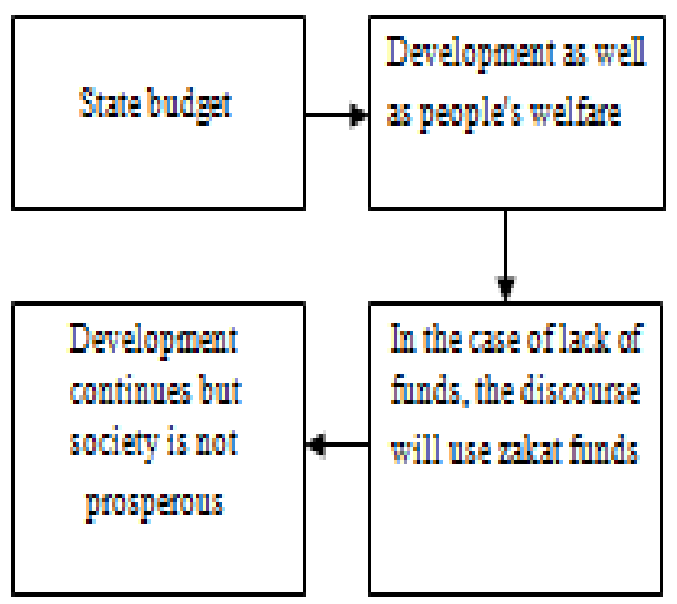

\subsection{Optimization of Zakat State Civil Apparatus in Poverty Reduction}

The occurrence of inequality was exacerbated by the policies of the governments of developing countries that are contrary to social interests. Imagine, while output decreases while social costs in order to accommodate the needs of the population are increasingly high (Michael P. Todaro, 1997: 214-215).

Between theory about the economic benefits of planning and practice there is a huge gap. Meanwhile, the gap between government rhetoric and economic reality is even greater. Although planning is widely believed to be able to eliminate or alleviate poverty, and reduce injustice and minimize unemployment, in reality practice planning in most developing countries has unwittingly conserved or even aggravated these circumstances. The failure of the planning process is caused by a number of specific problems as follows: (Michael P. Todaro, 1997: 216)

1. Limitations of the preparation of the plan and its implementation

2. Inadequate and unreliable data

3. External and internal economic turmoil that can not be anticipated before

4. Institutional weakness

5. Lack of political will

Planning and implementation of the plan can work well if supported by various parties with the totality of supporting the zakat ASN strategy as a step to alleviate poverty in order to be in harmony with the implementation so as to achieve the prosperity of the people as the aspiration.

Sufficient data must be held to be able to estimate the potential of acceptable zakat funds from ASN and all capable Muslims so as to eliminate external and internal economic turmoil and better yet to alleviate poverty and be a sustainable development step. Institutional strengthening must be implemented on the implementation of zakat ASN and all Muslims by generating political will to build the paradigm that zakat ASN which becomes the government discourse if added with the focus of maximizing the zakat of all Muslims in futuristic very potential to alleviate poverty and bring Indonesia to the prosperous condition and happy.

High and sustainable economic growth contributes greatly to poverty reduction (Tulus Tahi Hamonangan Tambunan, 2008: 134). The wisdom of worship is helping, helping, helping the needy and needy people, and balancing the use of wealth, so that the treasure is not only in the hands of the rich, zakat also creates and maintains unity, fraternal brotherhood mankind and cultivate social solidarity on an ongoing basis (Suparman Usman, 2002: 160-161). 
The subject matter of the economy concerns not only the economic aspects but also the aspects of history, sociology, perhaps even philosophy. And this is to be expected, because, after all, development is a human effort with a reach that reaches to the roots of our society (Richard T. Gill, 1983: 43).

The decision-making system of Government policy is a very important issue in the life of the nation. The Government Policy referred to herein is any decision made by the Government / State Officials on behalf of the agency he or she (President, Minister, Governor, Secretary-General, Director General, and so on) in order to carry out the general function of government or development in order to overcome certain problems to achieve certain objectives (Bintoro Tjokroamidjojo, 1988: 111)

The process of policy formulation and decision-making, this means that Pancasila should be the basis of value or criteria of assessment in determining the objectives and alternatives of government policy or political decision-making government in general. (Bintoro Tjokroamidjojo, 1988: 115)

The concept of zakat optimization in a country as already implemented by Malaysia and Saudi Arabia seems to have brought success. Malaysia considers zakat in every Constitution in its states and the result is capable of prospering the economy of the people. More neatly the concept of zakat in Saudi Arabia is much more integrated by utilizing information and technology that is to record nationally between the giver of zakat and the recipient of zakat so as to be able to alleviate the existing poverty. Indonesia needs to optimize the zakat ASN as an effort to alleviate poverty even more if all Muslims are appealed by the government through a rule of law on the implementation of zakat so that sustainable economic development can be implemented with the implementation of zakat through regulations and policies that support the implementation of zakat optimization.

\subsection{Barriers to the Implementation of Zakat State Civil Apparatus}

Fertility rates or high birth rates are often blamed as a major cause of poverty. To overcome this one of them by empowering domestic capital consisting of voluntary savings, community savings, government savings, savings coercion. Thus, through zakat as a voluntary savings and community savings managed by the government can alleviate poverty by enlarging the allocation of government savings for social assistance in an effort to prosper the community resulting in sustainable economic development with zakat as a solution.

The term "sustainable" or "sustainable" (economic sustainability) refers to "meeting the needs of the present generation without harming the needs of future generations". Or a new development process can be said to be sustainable if the total capital stock remains or increases over time (Lia Amalia, 2007: 39-40).

In reality, development in Indonesia can not be said to be a sustainable development, because in this case the existing development is using loans from abroad to thousands of trillions rupiah, of course this condition will harm the needs of future generations. Zakat ASN can enlarge social assistance funds in various fields provided by the government so that there is sustainable development by eliminating poverty through zakatr ASN to meet the needs of the present generation without harming the next generation.

According to Nurkse the vicious circle of poverty that occurs in underdeveloped countries slows down economic development. However, if the circle is solved, economic development will follow (M.L Jhingan, 2013: 182). Collective behavior and sub-optimality, assume that everyone in a group is a strong accepting candidate for collective goods. Each will act to maximize its own net benefits (Norman Frohlich, Joe A. Oppenheimer, 1984: 81)

In particular Smith praised the role of savings that is considered a very important factor for capital formation in the underdeveloped country. He wrote "every spender will be an enemy of society, and every sparing person will be generous." (M.L Jhingan, 2013: 87).

Economic growth studies the causes and ways of mass poverty alleviation. If basic consumption needs remain unfulfilled the poor suffer from a marked shortage. Perhaps even more sadly, poverty is by itself passed on to their children. The study of economic development must shortly grow from the most basic interests of the 
city, the situation of the masses of people forced to live in poverty (Bruce Herrick, Charles P. Kibndleberger 1988: 1-2).

\subsection{Legal Efforts to Optimize Zakah on Eradicating Poverty}

The link between zakat and poverty alleviation is very close, zakat optimization has a great opportunity to eliminate poverty. The capable society is shoulder to shoulder in the prosperous welfare so that the economic equality of the prosperous society can be created. Indonesia, which is predominantly Muslim, has the potential to help the government create social justice for all Indonesian people as the fifth principle of Pancasila.

In places where poverty has occurred for a long period is a temptation to explain it using a concept of economic equilibrium. J.K. Galbraith from Harvard has stated that development requires balance to be solved and that only "big" surprises can do that (Bruce Herrick, Charles P. Kibndleberger 1988: 12-13).

The state through its supreme authority commands humans as legal subjects to be obligated to obey orders (obliged), but not to create obligations. At least the command theory would force humans to conform to the law (Fajar Sugianto, 2013: 69).

Law and economics play a major role in creating and operating the law, so that law can truly distribute legal justice through economic efficiency of the economy. Of course the idea of justice according to the positivists is different from the legal and economic point of view. However, it is emphasized once more that the econom ic conception of justice helps to clarify the law's purpose in practice. In this picture, the law no longer creates rigidity of human interaction (as the perpetrators of economists and legal subjects), but the law (apparently) is able to create efficient regulation and can accommodate human needs. The existence of such a law law can be seen, perceived, and studied as a coherent system that ideally can explain, reappear and be in its place (Fajar Sugianto, 2013: 98).

There are some parties that support the allocation of zakat funds for infrastructure development, but it would be better if the zakat funds of ASN are allocated to increase social assistance funds in social, education, economic, natural disasters and various urgency needs for the welfare of the community.

We can affirm that a political will to build among national leaders (the will is their commitment to poverty alleviation efforts, income inequality and unemployment issues, and increase per capita GNP growth) should also be supported by forward insight and willingness to place social interests nationally above the interests of class or class, caste, tribe, individual, ethnicity, and so forth. This necessitates the implementation of cooperation between economic elites whose interests may at some cost be sacrificed for the sake of serving the common good (Michael P. Todaro, 1997: 218)

Instead, legislators should immediately legislate on matters related to regulations that support the implementation of zakat ASN and the zakat of all Muslims to run optimally so that such political will can prioritize the national interest by cooperating with parties potentially fulfilling the public interest and social interest for the welfare of society and sacrifice positively to jointly live happily without social inequality.

The economic elite, in this case the zakat giver ie ASN and other Muslim societies belonging to the category of capable people should help save the lives of underprivileged people with the discourse of zakat policy ASN to alleviate poverty. However, the government's policy in strengthening the implementation, management and implementation of zakat must be able to accommodate the proper implementation of zakat so that the achievement of the zakat objectives as contained in Article 3 letter b UUPZ.

There are many positive impacts if zakat is applied but the allocation should be to enlarge the social assistance funds provided by the government channeled for education, social, economic, natural disasters and the needs associated with the welfare of the people who are accommodated through zakat.

The law actually can play an important role to meet the human needs in the economic field for example by arranging the legal basis regarding the implementation of zakat ASN for optimal results can be felt even more if made a presidential regulation implication will apply to everyone. 


\section{Conclusion}

Zakat is very potential to alleviate poverty. Implementation and implementation of zakat has many positive impacts so it is urgency to be applied with the current poverty rate condition. The ideas that can be implemented by the government are:

1. The link between zakat and poverty alleviation is very close, zakat optimization has a great opportunity to eliminate poverty. A capable society in this case ASN and all Muslims must work hand in hand in the welfare of the people through zakat optimization.

2. Zakat ASN has the potential to alleviate poverty as a sustainable development step in Indonesia that is capable of bringing people to prosperity because social assistance, social, economic, education, natural disaster relief and other needs needed by the community can be enlarged with zakat funds of ASN and Islamic zakat funds.

Last of this scientific paper let me say thank you to:

1. Mr. Agussani, MAP as the Rector of Muhammadiyah University of North Sumatra that has supported the author.

2. Mother Dean of Law Faculty of Muhammadiyah University of North Sumatra and its staffs who have supported the author.

3. Mrs. Nursariani Simatupang, SH., MH. As a supervisor, giving guidance, advice and input in the completion of this scientific paper.

4. All Lecturers of the Faculty of Law University of Muhammadiyah North Sumatra or silmu who have been taught.

5. Parent writers who have provided moral and material support.

6. Friends and relatives of authors who always encourage.

\section{References}

[1] Bernard L. Tanya., Et al, The Theory of Law: The Orderly Strategy of Men Crossing Space and Generation, 2013, Yogyakarta: Genta Publishing.

[2] Bintoro Tjokroamidjojo, Development Policy and Administration, 1988, Jakarta: USAID.

[3] Bruce Herrick, Charles P. Kibndleberger, Development Economy, 1988, Jakarta: Bina Aksara.

[4] Fajar Sugianto, Economic Approach to Law Jakarta: Kencana Prenada Media Group.

[5] Lia Amalia, Development Economy, 2007, Yogyakarta: Graha Ilmu.

[6] M.L Jhingan, Economic Development and Planning, 2013, Jakarta: PT RajaGrafindo Persada.

[7] Michael P. Todaro, Economic Development in the Third World, 1997, Jakarta: Erland.

[8] Norman Frohlich, Joe A. Oppenheimer, Politics of Modern Economy, 1984, Jakarta: Bina Aksara.

[9] Peter Mahmud Marzuki, Legal Research, 2014 Jakarta: Prenada Media Group.

[10] Richard T. Gill, Development Economics Past and Present, 1983, Jakarta: Ghalia Indonesia.

[11] Soerjono Soekanto, Normative Legal Research, 2013, Jakarta: PT RajaGrafindo Persada.

[12] Suparman Usman, Islamic Law, 2002, Jakarta: The Primary Media Style.

[13] Tulus Tahi Hamonangan Tambunan, Economic Development \& Foreign Debt. 2008, Jakarta: PT RajaGrafindo Persada.

[14] Hendra Kurniawan, "How much Debt Children and Grandchildren Cover in Indonesia", www.politiktoday.com, accessed on March 03, 2018. 